\title{
MANAGEMENT OF ROOT-KNOT DISEASE OF POINTED GOURD THROUGH THE APPLICATION OF NEMATICIDES AND DIFFERENT ORGANIC AMENDMENTS
}

\author{
B. Akhter', M.R. Humaun² and K.U. Ahamed ${ }^{*}$
}

Received 29 September 2019, Revised 8 December 2019, Accepted 24 December 2019, Published online 31 December 2019

\begin{abstract}
A field experiment was conducted at Regional Agricultural Research Station, Bangladesh Agricultural Research Institute (BARI), Ishwardi, Pabna during 2013-14 to find out an effective integrated management package for controlling root knot nematode, Meloidogyne incognita of pointed gourd. The following treatments were $T_{1}=$ Spore suspension of $T$. harzanium added to around the roots of seedling, $\mathrm{T}_{2}=$ Dry neem leaves $@ 100 \mathrm{~g}^{-1}$ seedling ${ }^{-1}$, $\mathrm{T}_{3}=$ Furadan $5 \mathrm{G} @ 40 \mathrm{~kg} \mathrm{ha}^{-1}, \mathrm{~T}_{4}=$ Poultry litter @ $5 \mathrm{t} \mathrm{ha}^{-1}, \mathrm{~T}_{5}=$ Mustard oil cake @ $800 \mathrm{~kg}$ ha $^{-1}, \mathrm{~T}_{6}=$ Furadan $5 \mathrm{G}+$ Dry neem leaves, $\mathrm{T}_{7}=$ Furadan $5 \mathrm{G}+$ Poultry litter, $\mathrm{T}_{8}=$ Furadan $5 \mathrm{G}$ + Mustard oil cake and $\mathrm{T}_{9}=$ Control were tested for their performance against the disease. Gall index ranged from 3.33-7.67. Significantly lower gall index (3.33) was recorded in treatment $\mathrm{T}_{7}=$ Furadan $5 \mathrm{G}+$ Poultry litter and maximum gall index (7.67) was recorded in treatment $\mathrm{T}_{9}=$ Control plot. The highest yield $\left(24.97 \mathrm{t} \mathrm{ha}^{-1}\right)$ was recorded in Furadan $5 \mathrm{G}+$ Poultry litter treated plot where are the lowest yield $\left(7.53 \mathrm{t} \mathrm{ha}^{-1}\right)$ was in Control plot. The incorporation of Poultry litter with Furadan $5 \mathrm{G}$ increased the efficiency of the treatment and gave satisfactory result to reduce root knot disease and to improve plant growth and yield of pointed gourd.
\end{abstract}

Keywords: Root Knot Disease, Pointed Gourd, Nematicides, Organic Amendments.

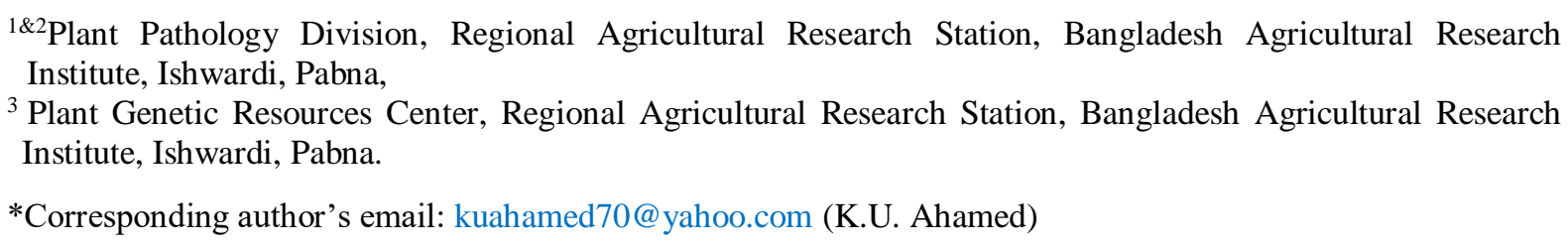

Cite this article as: Akhter, B., Humaun, M.R. and Ahamed, K.U. 2019. Management of root-knot disease of pointed gourd through the application of nematicides and different organic amendments. Int. J. Agril. Res. Innov. Tech. 9(2): 51-56. DOI: 10.3329/ijarit.v9i2.45410.

\section{Introduction}

Pointed gourd (Trichosantes dioica Roxb.) is one of the popular cucurbitaceous vegetables cultivated in Bangladesh. Pointed gourd is an important vegetable during the lean period. Fruits are harvested during the entire period of summer and rainy season. It is morphologically distinct from other cucurbitaceous species due to its well-established dioecism, perennial nature, and vegetative means of propagation. Fruits of pointed gourd are rich in proteins and vitamin A and also possess medicinal properties that can lower blood sugar and serum triglycerides. Yield of pointed gourd is very low compared to other pointed gourd producing countries. There are several reasons for low yield of pointed gourd in this country. Root knot is a major disease of pointed gourd that causes severe yield loss. The crop is found to be susceptible Meloidogyne sp.
The root system of the crop is converted to big gall due to the infection of the nematode. Finally, the root become rot in the rainy season and yield reduced. Root knot nematodes cause histopathological changes in root tissues of pointed gourd resulting the formation of giant cells and galls in the root system. This abnormality can upset the normal physiological activities of vascular tissue of the root system and finally causes wilting, stunting, leaf chlorosis and poor growth of plants (Ekanayake et al., 1988). Root knot nematodes contribute to retardation of seedling growth, plant damage, sudden death and concomitant yield losses (Campos and Villain, 2005; Orisajo et al., 2008). Farmers generally use fungicides/nematicides to control the disease. Control of nematodes with nematicides is effective but costly and it may create 
environmental pollution and residual problems. However, sole dependency on different chemicals may cause environmental pollution and pathogen resistance to pesticides. For decades, the control of plant-parasitic nematodes has been achieved mainly using chemical nematicides (Afolami, 1993). In addition; the pesticides are relatively unaffordable to many small scale farmers. These findings also reported that owing to environmental pollution and costliness of synthetic pesticides, chemical control no longer holds sway in sustainable agricultural production (Hassan et al., 2001). The employment of various sources of organic materials has been promoted as one of the principal sustainable management options for improving soil quality and productivity (Widmer et al., 2002). Organic amendments such as green manure, crop residues, cow dung and poultry manure used to improve soil fertility, have also been found to control root diseases including nematodes (Poswal and Akpal, 1991). The application of organic amendment to the soil as an alternative strategy for the management of plant-parasitic nematodes, have been proved substantially increase soil health (Neher, 2001), environmental wellness (Adegbite and Adesiyan, 2005) and sustainable crop production with no documented negative effect of organic soil amendment on non-target organisms (Agyarko and Asante, 2005). Oka et al. (2000) indicated that organic addition have constantly produced beneficial effects on soil nutrients, soil physical conditions, and soil biological activities thereby improving the health of plants and reducing populations of plant-parasitic nematodes. Kimenju et al. (2004) also reported that application of organic amendment stimulated the activity of natural antagonists of plant-parasitic nematodes by stimulating the occurrence of nematode destroying fungi in the soil. The control of plantparasitic nematodes has been successful with poultry manure, cow dung and sawdust (Egunjobi and Larinde, 1975; Babatola, 1982; Chindo et al., 1991). On cowpea, Olabiyi et al. (2007) also reported a significant reduction in root galls and improved growth yield on soil amended with organic manure. In a cacao establishment, addition of poultry litter also suppressed populations of Meloidogyne incognita and stimulated growth of cacao seedlings (Orisajo et al., 2008). Agu (2008a) evaluated different organic manures (municipal garbage, swine, compost, poultry and farmyard manure application) for effective control of root-gall nematode disease on African yam bean and indicated that plants treated with poultry and farmyard manures gave significantly higher yields than those of other organic manures. He also showed that root-gall nematode damage on pineapple was best controlled with poultry manure application (Agu, 2008b). Therefore the focus of this research is the suppressive effects of poultry manure in combination with Furadan-5G on plant-parasitic nematodes and subsequently, on pointed gourd yield.

\section{Materials and Methods}

The field experiment was carried out during October 2013- October 2014, at the experimental field of RARS, BARI, Ishwardi, Pabna. The field was prepared with power tiller and prepared raised pit with keeping $1 \mathrm{~m}$ distance from pit to pit. The unit plot size was $2.0 \mathrm{~m} \times 1.2 \mathrm{~m}$. Nine treatments viz. $\mathrm{T}_{1}=$ Spore suspension of $T$ harzanium added to around the roots of seedling, $\mathrm{T}_{2}=$ Dry neem leaves $@ 100 \mathrm{~g}$ seedling ${ }^{-1}, \mathrm{~T}_{3}=$ Furadan 5G@ $00 \mathrm{~kg} \mathrm{ha}^{-1}, \mathrm{~T}_{4}=$ Poultry litter @5 t ha $^{-1}, \mathrm{~T}_{5}=$ Mustard oil cake @ $800 \mathrm{~kg} \mathrm{ha}^{-1}, \mathrm{~T}_{6}=$ Furadan $5 \mathrm{G}+$ Dry neem leaves, $\mathrm{T}_{7}=$ Furadan $5 \mathrm{G}$ + Poultry litter, $\mathrm{T}_{8}=$ Furadan $5 \mathrm{G}+$ Mustard oil cake and $\mathrm{T}_{9}=$ Control were included in this experiment. Treatments were replicated three times in a Randomized Complete Block Design. Poultry litter, dry neem leaves and Mustard Oil cake were applied three weeks before planting and incorporated with the soil properly for well decomposition. The nematicide, Furadan $5 \mathrm{G}$ was applied at the time of planting. Vine of BARI Patal-1 were planted in the pits. After harvesting the fruits, plants were uprooted to observe the gall. Data were recorded on gall index (0-10 scale), number of fruits plant ${ }^{-1}$, weight of fruits plant $^{-1}$ and yield. The scale was $0=$ complete and healthy root system, no infestation, 1 = Very few small galls can only be detected upon close examination, 2 = Small galls but easily detected, 3 = Numerous small galls, some grown together, but function of roots not seriously affected, $4=$ Numerous small galls, some big galls, majority of roots still functioning, $5=25 \%$ of root system severely galled and not functioning, $6=50 \%$ of root system severely galled and not functioning, 7 $=75 \%$ of root system severely galled and last for production, $8=$ No healthy roots, nourishment of plants interrupted, plants still green, $9=$ Completely galled root system is rotting, plant is dying, $10=$ Plants and roots are dead. The recorded data were analyzed statistically to find out the level of significance and the variations among the respective data were compared following Duncan's New Multiple Range Test (DMRT).

\section{Results}

The result showed that plots amended with Furadan $5 \mathrm{G}+$ Poultry liter treatments reduced the infection of plant-parasitic nematodes that were associated with pointed gourd plants. Soil treated with Furadan $5 \mathrm{G}+$ Poultry liter gave the most effective nematode control when compared 
with Furadan 5G and Poultry liter alone and the untreated control plots. The highest gall index value of 7.67 was observed from control plot and the lowest gall index 3.33 from poultry liter in combination with Furadan 5G. Treatment $\mathrm{T}_{7}=$ Furadan + Poultry litter decreased $56.58 \%$ gall index over control (Table 1).

Table 1. Effect of treatments on gall index of pointed gourd plant.

\begin{tabular}{|c|c|c|}
\hline Treatments & $\begin{array}{l}\text { Gall index } \\
(0-10 \text { scale })\end{array}$ & $\begin{array}{l}\text { Gall index decreased } \\
\text { over control (\%) }\end{array}$ \\
\hline $\begin{aligned} & \mathrm{T}_{1}= \text { Spore suspension of } T \text {. harzanium added to } \\
& \text { around the roots of seedling }\end{aligned}$ & $7.00 \mathrm{a}$ & 8.73 \\
\hline $\mathrm{T}_{2}=$ Dry neem leaves $@ 100$ g seedling ${ }^{-1}$ & $7 \cdot 33 \mathrm{a}$ & 4.43 \\
\hline $\mathrm{T}_{3}=$ Furadan $5 \mathrm{G} @ 40 \mathrm{~kg} \mathrm{ha}^{-1}$ & $4.33 \mathrm{~b}$ & 43.54 \\
\hline $\mathrm{T}_{4}=$ Poultry litter @ $5 \mathrm{t} \mathrm{ha}^{-1}$ & $4.33 \mathrm{~b}$ & 43.54 \\
\hline $\mathrm{T}_{5}=$ Mustard Oil cake @ $800 \mathrm{~kg} \mathrm{ha}^{-1}$ & $6.33 \mathrm{a}$ & 17.47 \\
\hline $\mathrm{T}_{6}=$ Furadan + Dry neem leaves & $4.00 \mathrm{~b}$ & 47.84 \\
\hline $\mathrm{T}_{7}=$ Furadan + Poultry litter & $3.33 \mathrm{~b}$ & 56.58 \\
\hline $\mathrm{T}_{8}=$ Furadan + Mustard Oil cake & $4.33 \mathrm{~b}$ & 43.54 \\
\hline $\mathrm{T}_{9}=$ Control & $7.67 \mathrm{a}$ & - \\
\hline CV (\%) & 14.07 & \\
\hline LSD & 1.305 & \\
\hline F-test & $* *$ & \\
\hline
\end{tabular}

Pointed gourd plots amended with poultry liter + recorded from Furadan $5 \mathrm{G}+$ Poultry litter treated Furadan $5 \mathrm{G}$ treatments supported good fruit yield plot and the lowest (22.67) was recorded from of pointed gourd. Different yield attributes control plot (Fig. 1). The highest fruit weight (number of fruits, weight of fruits) of pointed plant-1 $(3 \mathrm{~kg}$ ) was recorded from Furadan $5 \mathrm{G}+$ gourd plant are presented in fig. 1 and 2. The Poultry litter treated plot and the lowest $(0.9 \mathrm{~kg})$ highest number of fruits per plant (59.33) was was recorded from control plot. Fig. 2.

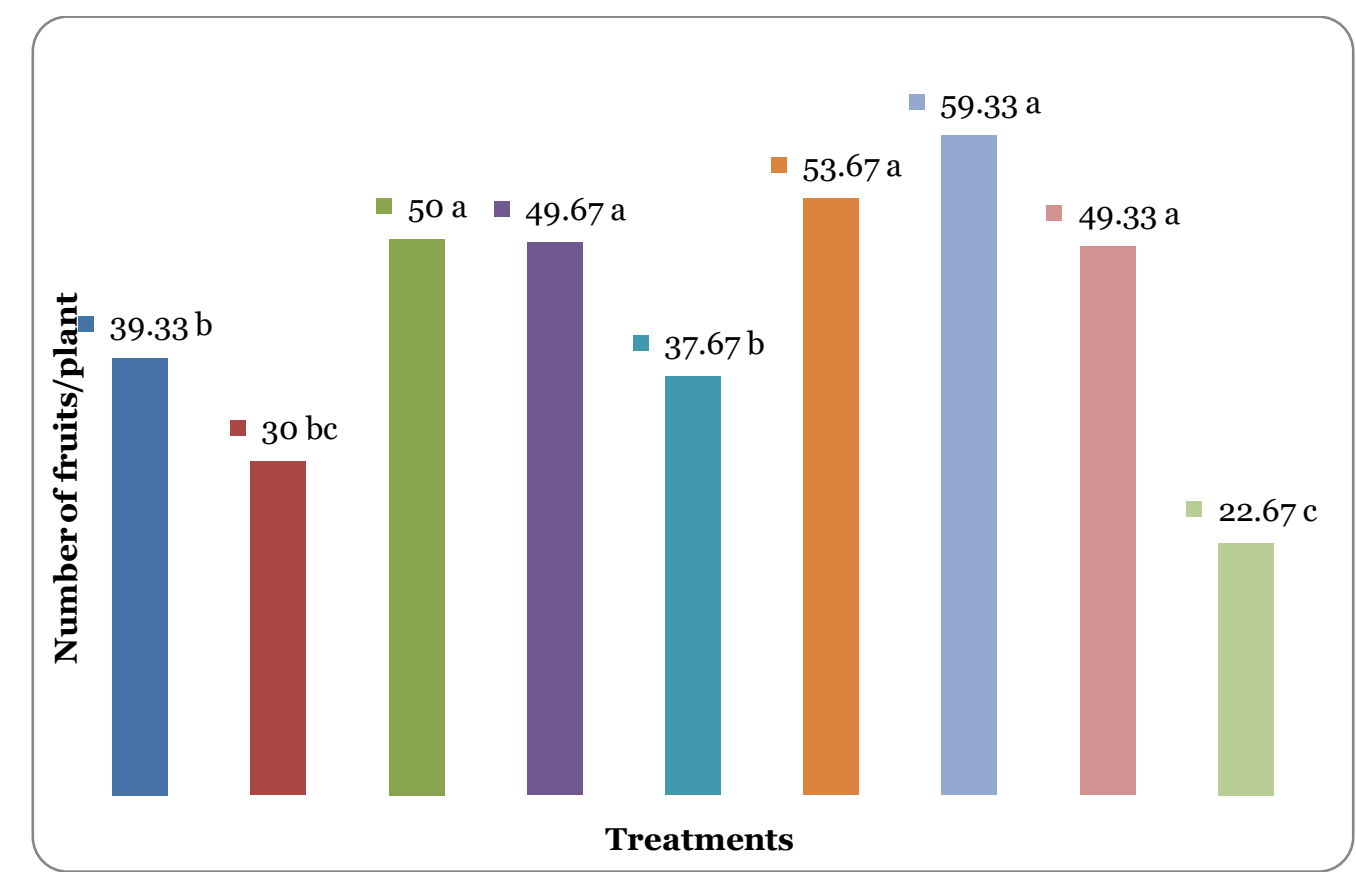

Fig. 1. Effect of treatments on number of fruits plant ${ }^{-1}$ of pointed gourd. 


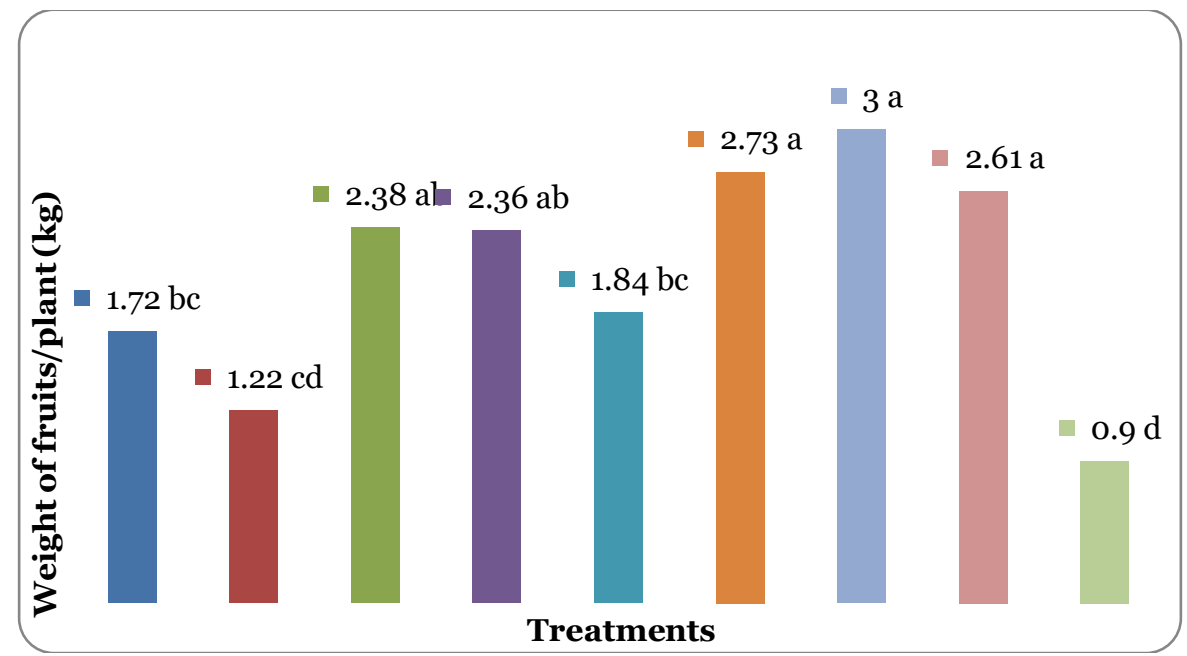

Fig. 2. Effect of treatments on weight of fruits plant ${ }^{-1}(\mathrm{~kg})$ of pointed gourd.

Table 2. Effect of treatments on yield of pointed gourd plant.

\begin{tabular}{|c|c|c|}
\hline Treatments & $\begin{array}{l}\text { Yield } \\
\left(\mathrm{t} \mathrm{ha}^{-1}\right)\end{array}$ & $\begin{array}{l}\text { Yield increased } \\
\text { over control (\%) }\end{array}$ \\
\hline $\begin{array}{l}\mathrm{T}_{1}=\text { Spore suspension of } T . \text { harzanium added to around } \\
\text { the roots of seedling }\end{array}$ & $14.30 \mathrm{c}$ & 89.90 \\
\hline $\mathrm{T}_{2}=$ Dry neem leaves @ 100 g seedling $^{-1}$ & $10.58 \mathrm{~d}$ & 40.50 \\
\hline $\mathrm{T}_{3}=$ Furadan 5G @ 40 kg ha-11 & $19.80 \mathrm{~b}$ & 162.94 \\
\hline $\mathrm{T}_{4}=$ Poultry litter @ $5 \mathrm{t} \mathrm{ha}^{-1}$ & $19.67 \mathrm{~b}$ & 161.22 \\
\hline $\mathrm{T}_{5}=$ Mustard Oil cake @ $800 \mathrm{~kg} \mathrm{ha}^{-1}$ & $15.33 \mathrm{c}$ & 103.58 \\
\hline $\mathrm{T}_{6}=$ Furadan + Dry neem leaves & $22.78 \mathrm{ab}$ & 202.52 \\
\hline $\mathrm{T}_{7}=$ Furadan + Poultry litter & $24.97 \mathrm{a}$ & 231.60 \\
\hline $\mathrm{T}_{8}=$ Furadan + Mustard oil cake & $21.75 \mathrm{ab}$ & 188.84 \\
\hline $\mathrm{T}_{9}=$ Control & $7.53 \mathrm{~d}$ & - \\
\hline CV (\%) & 11.56 & - \\
\hline LSD & 3.453 & - \\
\hline F-test & $* *$ & - \\
\hline
\end{tabular}

Correlation and regression coefficients were relationship showed that the yield was strongly estimated between gall index and yield of pointed negatively correlated with gall index under soil gourd (Fig. 3). The regression and correlation amendments. The regression lines indicate that between gall index and yield of pointed gourd was with the increase of gall index decreases the yield obtained as equation $\mathrm{y}=35.93-0.3 \cdot 425 \mathrm{x}$ and of pointed gourd.

correlation coefficient $\mathrm{r}=-0.9705$. The

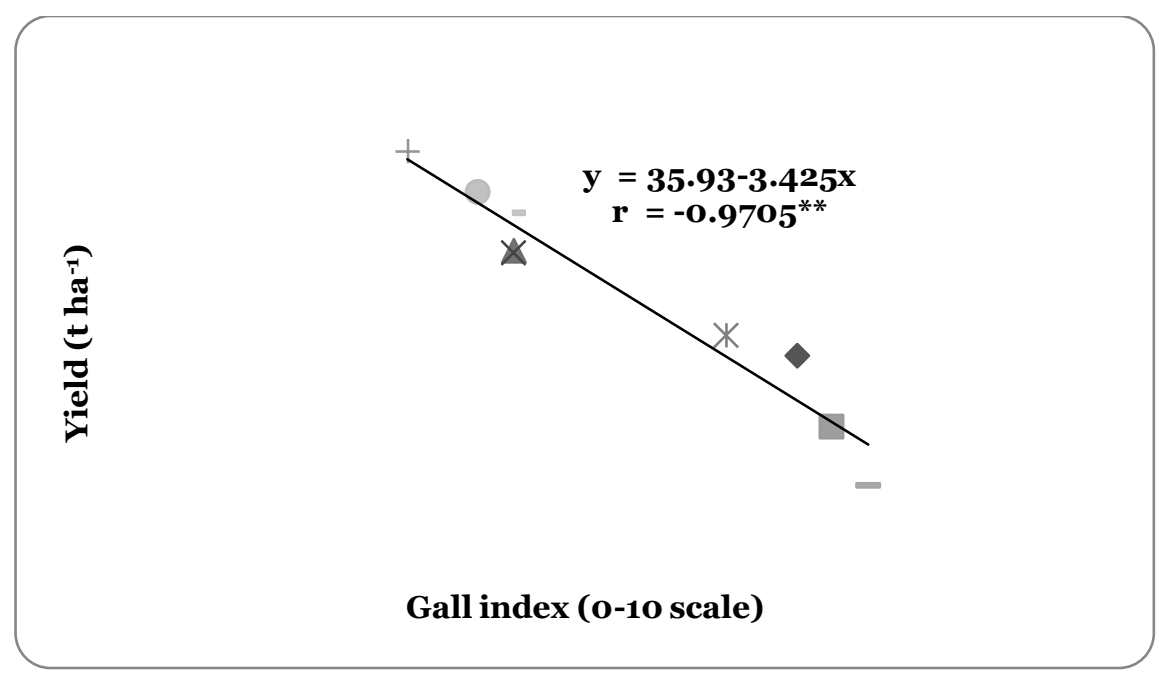

Fig. 3. Relationship between incidence of gall index (o-10 scale) and yield ( $\mathrm{t} \mathrm{ha}^{-1}$ ) of pointed gourd. 


\section{Discussion}

The result of this study showed that Furadan $5 \mathrm{G}$ + Poultry liter amendments significantly reduced the gall index of nematodes in the fields. The use of chemical nematicides has been described as the quickest and most effective control of plantparasitic nematodes especially when crop failure is eminent (Rohrbach and Apt, 1986; Afolami, 1993; Aktar and Malik, 2000). The nematostatic action of Furadan $5 \mathrm{G}$ in nematode control could be responsible for significantly low gall index recorded in different vegetable fields. Whereas fumigant nematicides cause a high degree of nematode mortality in the soil. Effects of carbofuran on nematodes have been described as reversible, therefore nematode activity is restored after degradation or dilution of the carbamates in the plant rhizosphere (Sikora and Hartwig, 1991; EXTOXNET, 2001). Significant increase in the vegetative growth and yield of pointed gourd following the application of Furadan $5 \mathrm{G}+$ Poultry litter treated plots were also recorded. Furadan $5 \mathrm{G}+$ Poultry litter treated plants had good vegetative growth. This level of vegetative growth implies higher rate of photosynthesis and fruit production of the plants. The result of this study showed that Furadan 5G in corporations with poultry manure significantly reduced the gall index of plant-parasitic nematodes. This observation agreed with that of Agu (2008a) and Agu (2008b) who reported significant control of root-gall disease of pineapple with poultry manure. Poultry manure contains a significant amount of nitrogen, the majority of which is in the form of uric acid that can be easily converted to ammonia, which is lethal to plant-parasitic nematodes. According to Riegel and Noe (2000), suppression of nematodes by poultry litter is probably a combination of enhanced microbial activity and constituent toxicity to crops. Nematode population densities have also been negatively correlated with fruit weight of pineapple (Schenck and Holtzmann, 1990). Rohrbach and Apt (1986) proposed that plantparasitic nematodes could cause significant yield losses and in some cases lead to complete devastation of the crop due to their feeding activities of crops roots. Therefore, suppressive effect of poultry liter on the gall index in the pointed gourd plots could have resulted in the improved yield recorded on the Furadan $5 \mathrm{G}+$ poultry liter-amended plots. The present study recorded significantly higher vegetative growth, number of fruits plant ${ }^{-1}$ and fruit sizes on Furadan $5 \mathrm{G}+$ poultry liter-treated plot. Soil amendment with poultry liter has been shown to consistently improve the health of plants while reducing the populations of plant-parasitic nematodes (Oka et al., 2000; Orisajo et al., 2008). Poultry liter contains significant quantities of $\mathrm{N}, \mathrm{P}, \mathrm{K}, \mathrm{Ca}, \mathrm{Mg}$ and micronutrients. The Nitrogen content of poultry liter also contains significant amounts of uric acid, which is readily decomposable and available to plants (Hue and Silvia, 2000) for enhanced plant growth and yield. The application of poultry liter to the pointed gourd plots could have contributed to the concentration of nutrients within and below the root zone of the pointed gourd plants. The resultant effect of which is increased yield recorded.

\section{Conclusion}

It is evident from the above results that Furadan $5 \mathrm{G}+$ poultry liter is effective in suppressing or reducing root knot nematode associated with pointed gourd. Furadan $5 \mathrm{G}$ combination with poultry liter showed better performance in respect of reduce gall index and increase yield of pointed gourd than others treatment.

\section{References}

Adegbite, A.A. and Adesiyan, S.O. 2005. Root extracts of plants to control root-knot nematode on edible soybean. World J. Agril. Sci. 1: 18-21.

Afolami, S.O. 1993. The Effect of Basamid Granular (Dazomet) on nematodes parasitic on cacao seedlings in the nursery. pp. 237240. In: Proceedings, $11^{\text {th }}$ International Cocoa Research Conference, Bahia, Brazil.

Agu, C.M. 2008a. Effects of Organic Manure Types on Root-Gall Nematode Disease and African Yam Bean Yield. The J. American Sci. 4(1): 76-79.

Agu, C.M. 2008b. Root-Gall Disease of Pineapple as Affected by Seed Material, Amount and type of Organic Soil Amendment. Plant Sci. Res. 1(2): 36-39.

Agyarko, K. and Asante, J.S. 2005. Nematode Dynamics in Soils Amendment with Neem Leaves and Poultry Manure. Asian J. Plant Sci. 4(4): 426-428.

Aktar, A. and Malik, A. 200o. Roles of organic soil amendment and soil organisms in the biological control of plant-parasitic nematodes: A review. Bioresource Tech. 74(1): 35-47.

Babatola, J.O. 1982. Effects of soil amendments in tomato cultivation. pp. 21-25. In: Proc. $5^{\text {th }}$ Annual Conf. Horticultural Society of Nigeria, Ahmadu Bello University, Zaria Nigeria.

Campos, V.P. and Villain, L. 2005. Nematode parasites of coffee and cocoa. pp. 529-579. In: Plant-Parasitic Nematodes in Subtropical and Tropical Agriculture, $2^{\text {nd }}$ Edition, (eds M. Luc, R.A. Sikora, and J. Bridge). Wallingford, UK: CAB International. 
Chindo, P.S., Khan, F.A. and Erinle, I.D. 1991. Reaction of three tomato cultivars to two vascular diseases in presence of the rootknot nematode Meloidogyne incognita Race I. Crop Protect. 10: 62-64.

Egunjobi, O.A. and Larinde, M.A. 1975. Nematodes and maize growth in Nigeria.II. Effects of some amendments on populations of Pratylenchus brachyurus and on the yield of maize (Zea mays) in Nigeria. Nematol. Medit. 3: 65-73.

Ekanayake, H., Vito, M.R.K.M.D. and Vovlus, N. 1938. Histopathological changes caused by Meloidogyne incognita on tomato and egg plant roots. Trop. Agric. 114: 89-97.

EXTOXNET. 2001. Carbofuran. Available online http://ace.ace.orst.edu/info/extoxnet/pips/c arbofur.htm

Hassan, S.M.E., Rahman, M.S., Amin, M.R., Hoque, A.T.M.R. and Islam, S.M.S. 2001. Effect of some organic substances on the root-knot disease of Brinjal. Online J. Biol. Sci. 1: $791-792$.

Hue, N.V. and Silvia, J.A. 2000. Organic soil Amendments for Sustainable Agriculture: Organic sources of Nitrogen, Phosphorus and Potassium. pp. 133-144. In: Plant Nutrient Management in Hawaii's Soils, Approaches for Tropical and Subtropical Agriculture. J. A. Silva and R. Uchida (eds.) College of Tropical Agriculture and Human Resources, University of Hawaii at Manoa.

Kimenju, J.W., Muiru, D.M., Karanja, N.K., Nyongesa, M.Y. and Miano, D.N. 2004. Assessing the role of organic amendment in the management of Root-knot nematodes on common bean, Phaseolus vulgaris L. Trop. Micobiol. Biotech. 3: 14-23.

Neher, D.A. 2001. Role of nematodes in soil health and their use as bioindicators. $J$. Nematol. 33: 161-168.
Oka, Y., Nacar, S., Putieusky, E., Ravid, U., Zohara, Y. and Spiegal, Y. 200o. Nematicidal activity of essential oils and their components against the root knot nematode. Phytopath. 90(7): 710-715.

Olabiyi, T.I., Akanbi, W.B. and Adepoju, I.O. 2007. Control of certain nematode pests with different organic manure on cowpea. American-Eurasian J. Agric. Environ. Sci. 2(5): 523-527.

Orisajo, S.B., Afolami, S.O., Fademi, O. and Atungwu, J.J. 2008. Effects of poultry litter and Carbofuran soil amendments on Meloidogyne incognita attacks on cacao. $J$. Appl. Biosci. 7: 214-221.

Poswal, M.A.T. and Akpal, A.D. 1991. Current trends in the use of traditional and organic methods for the control of crop pests and diseases in Nigeria. Trop. Pest Mgmt. 37: 329-333.

Riegel, C. and Noe, J.P. 2000. Chicken litter soil amendment effects on soil borne microbes and Meloidogyne incognita on cotton. Plant Dis. 84: 1275-1281.

Rohrbach, K.G. and Apt, W.J. 1986. Nematode and disease problems of Pineapple. Plant Dis. 70: 81-87.

Schenck, S. and Holtzmann, O. 1990. Evaluation of Potential Problems in a changing Agricultural systems: Nematodes control in Hawaiian crops. Plant Dis. 74(11): 837-843.

Sikora, R.A. and Hartwig, J. 1991. Mode-of-action of the carbamate nematicides cloethocarb, aldicarb and carbofuran on Heterodera schachtii. 2. Systemic activity. Rev. nematol. 14(4): 531-536.

Widmer, T.L., Mitkowski, N.A. and Abawi, G.S. 2002. Soil Organic Matter and Management of Plant-Parasitic Nematodes. J. Nematol. 34(4): 289-295. 